\title{
Reed Sternberg Cells in Bone Marrow Touch Imprints
}

\section{Andrea Patriarca* and Giulio Giordano}

Department of Hematology, Ospedale Civile dello "Spirito Santo", Pescara, Italy

"Corresponding author: Andrea Patriarca, Department of Hematology, "Spirito Santo" Hospital, 65124, Pescara, Italy, Tel: +39-085/4252810; Fax: +39-085/4252857; E-mail: andreapatriarca80@gmail.com

Received date: June 29, 2015, Accepted date: June 30, 2015, Publication date: July 03, 2015

Copyright: (C) 2015 Patriarca A, et al. This is an open-access article distributed under the terms of the Creative Commons Attribution License, which permits unrestricted use, distribution, and reproduction in any medium, provided the original author and source are credited.

\section{Clinical Image}

A 65-year-old male presented with weakness, weight loss, and recurrent fever for 14 months. Hemoglobin was $11.6 \mathrm{~g} / \mathrm{dL}$, with normal mean corpuscular volume, mean corpuscular hemoglobin. White blood cells were $4.0 \times 10^{9} / \mathrm{L}$ with a slight monocytosis and platelets were in normal range. Blood chemistry showed: lactate dehydrogenase $621 \mathrm{IU} / \mathrm{L}$, total bilirubin $1.2 \mathrm{mg} / \mathrm{dL}$, alkaline phosphatase $427 \mathrm{IU} / \mathrm{L}$, and serum creatinine $0.6 \mathrm{mg} / \mathrm{dL}$. Nor significant lymphadenopathy nor hepato-splenomegaly was found on clinical examination. Considering the persistence of symptoms a bone marrow aspirate and a trephine biopsy were done. Bone marrow aspirate was a dilute specimen, while touch imprint was cellular with trilineage hematopoiesis. Numerous Reed-Sternberg cells (R-S) were seen in touch imprints (Figure 1, panels A-B). These were large cells having abundant basophilic cytoplasm, bilobed nuclei with eosinophilic nucleoli (marked by arrow). Bone trephine was hyperplastic with diffuse infiltration by inflammatory and R-S cells (Figure 1, panel C) strongly expressing CD 15 and CD30 (Figure 1, panel D). The patient is currently on chemotherapy and is improving clinically.

Bone marrow infiltration is observed in only $5 \%$ to $15 \%$ of patients with Hodgkin disease. The presence of R-S cells in bone marrow is required for primary diagnosis of lymphoma. This may not be the case if marrow is done for staging purposes. However, careful examination of touch imprints of bone marrow itself can be diagnostic and helpful in the management of the patient.

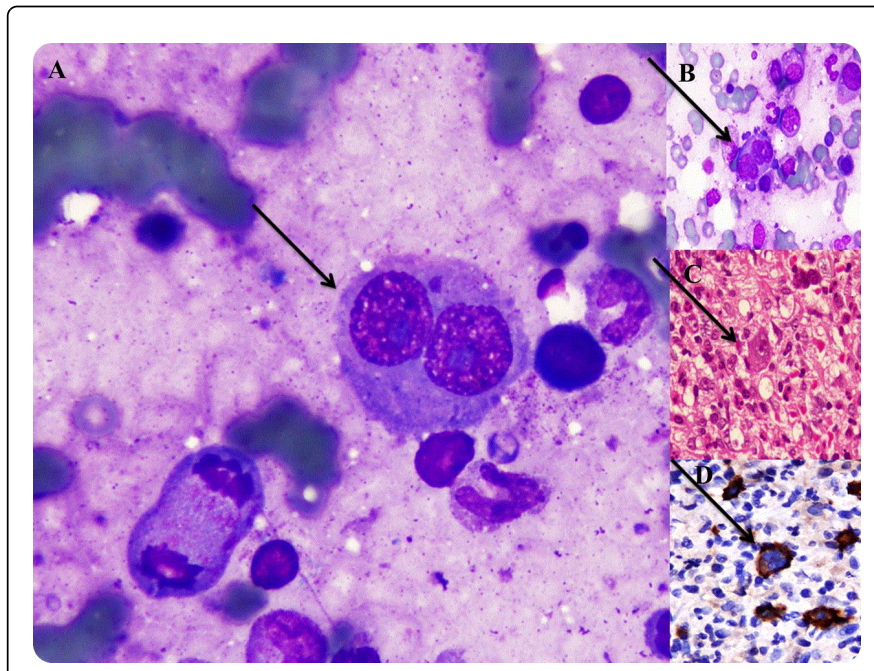

Figure 1: Reed sternberg cells in bone marrow. 